\title{
Chitosan and $\beta$-amino butyric acid up-regulates transcripts of resistance gene analog RGPM213 in pearl millet to infection by downy mildew pathogen
}

\author{
P. Ranjini ${ }^{1}$, Melvin $\operatorname{Prasad}^{2}$, J. Samanth $\mathrm{Kumar}^{2}$, Shailasree Sekhar ${ }^{3 *}$, Devaraju Kesagodu ${ }^{4}$, H. Shekar Shetty ${ }^{2}$, \\ K. Ramachandra Kini ${ }^{2}$ \\ ${ }^{1}$ Department of Biotechnology, Maharani’s Science College for Women, University of Mysore, Mysore-570005, Karnataka, India. \\ ${ }^{2}$ Department of Studies in Biotechnology, Manasagangotri, University of Mysore, Mysore- 570005, Karnataka, India. \\ ${ }^{3}$ Institution of Excellence, Vijnana Bhavana, Manasagangotri, University of Mysore, Mysuru - 570 006. Karnataka.India. \\ ${ }^{4}$ Department of Chemistry, Yuvaraja's college, University of Mysore, Mysore-570005, Karnataka, India.
}

\begin{tabular}{|c|c|}
\hline ARTICLE INFO & ABSTRACT \\
\hline $\begin{array}{l}\text { Article history: } \\
\text { Received on: } 15 / 06 / 2016 \\
\text { Revised on: } 30 / 07 / 2016 \\
\text { Accepted on: } 02 / 09 / 2016 \\
\text { Available online: } 23 / 10 / 2016\end{array}$ & $\begin{array}{l}\text { Plants are hosts to a diverse group of pathogens belonging to different kingdoms of life. In absence of active } \\
\text { immune system, plants have evolved several layers of defense to combat individual pathogen strain and evolving } \\
\text { pathogen populations. Management of various plant pathogen infections necessitates the use of multiple resistance } \\
(R) \text { genes, which requires efficient and accurate practices for identification, isolation and characterization of } R \\
\text { genes. This knowledge helps to probe } R \text { gene(s) in a host plant and sort out their functional redundancy and }\end{array}$ \\
\hline $\begin{array}{l}\text { Key words: } \\
\text { Resistance gene analog } \\
\text { (RGA), Pearl millet, RT- } \\
\text { PCR, Transcript, Plant } \\
\text { defense. }\end{array}$ & $\begin{array}{l}\text { specificity. Pearl millet [Pennisetum glaucum (L.) R. Br.] is highly nutritive, summer-annual forage crop, drought } \\
\text { tolerant cereal, staple food crop of the semi-arid tropics but is highly susceptible to the downy mildew disease } \\
\text { caused by oomycetous Sclerospora graminicola (Sacc.) schroet. Earlier studies have identified several resistance } \\
\text { gene analogues (RGAs) in pearl millet which may be involved in resistance against downy mildew. Of these, a } \\
\text { clone RGPM } 213 \text { was shown to encode resistant protein having serine threonine kinase domain and its transcript } \\
\text { was upregulated following S. graminicola infection and } \beta \text {-amino butyric acid an abiotic inducer treatment. Here } \\
\text { we have shown the accumulation of transcripts of RGPM } 213 \text { in pearl millet during treatment with Chitosan, a } \\
\text { chitin derivative, a known inducer of plant defense which is completely safe, characterized by unique properties, } \\
\text { like bioactivity and biocompatibility. }\end{array}$ \\
\hline
\end{tabular}

\section{INTRODUCTION}

Plants cope with pathogen infection through various complex adaptive responses. Some of the responses are constitutive and pathogen non-specific, but most of them are induced after recognition of the pathogen. In plants, stimuli like pathogen, biotic and abiotic elicitors perturb the redox balance of the cell and further induce the expression of defense-related genes. Most of the plant pathogen interactions symbolically mimic a war. In this, plants employ two layers of defense against the invaders

* Corresponding Author

Shailasree Sekhar, Assistant Professor, Institution of Excellence, Vijnana Bhavana, Manasagangotri, University of Mysore, Mysuru - 570006.

Karnataka, India. Email: shailashree @ioe.uni-mysore.ac.in and sacrifice some host components as the representative of severe cause [1]. Depending on the severity of the responses, a plant may succumb to the invaders (compatible interactions), or prevent the pathogen from colonizing it (incompatible interactions).

This perturbation in plants activates sophisticated recognition system [Resistance $(\mathrm{R})$ proteins] to detect pathogen specific elicitors [Avirulence (Avr) proteins] in a highly specific manner by gene for gene interaction (R-Avr interaction).

The majority of R-proteins that are activated upon effector recognition are categorized into 7 distinct classes depending upon the combination of the structural motifs [2]. These plant proteins share a similar structure characterized by a nucleotide binding site (NBS) and leucine-rich repeats (LRR). 
Currently, cloning of resistance $(R)$ genes using degenerate primer based technique has made the availability of cloned $R$ genes for genetic transformation and their modification. This has opened the possibility of direct transfer into elite lines within a single generation. The introduction of $R$ genes by plant transformation also removes the barriers presented when interspecies infertility prevents gene introduction by traditional plant breeding.

This makes it feasible to identify a useful $R$ gene in a wild plant species and transfer the gene into a crop plant. Plant transformation also offers the immediate possibility of introducing simultaneously several different $R$ gene alleles that are effective against a single pathogen species. In theory, this should slow the process of microbe evolution, because the various $R$ genes should be overcome only if all the corresponding avirulence $(A v r)$ gene products mutate simultaneously within a single pathogen isolate [3-13]

Pennisetum glaucum (L.) R. Br. is the most widely grown millet has had an important impact on small farmer welfare in India. It is highly adaptable to extreme conditions like drought and serves as staple food crop of semiarid tropical region. It is endowed with high protein content and energy density [14]. It's succumbed to the infection caused by oomycetous Sclerospora graminicola (Sacc) shroet. The resistance gene analog (RGA) RGPM 213 has shown 56\% identity to rice R-proteins.

This RGA is identified to encode for serine threonine protein kinase [15], upregulated following Sclerospora graminicola infection and $\beta$-amino butyric acid (BABA) an abiotic inducer treatment [16]. To unravel the functional role of RGPM 213 gene in pearl millet host pathogen interaction, the present investigation was made to elucidate transcriptional expression of this RGCs followed by seed treatment with chitosan a known inducer of resistance in pearl millet.

Radiolabelled RGPM 213 cDNA was used as a probe to know the up/down regulation of transcripts in an inducer treated pearl millet following inoculation with pathogen $S$. graminicola. Previously raised polyclonal antibodies against His-tagged RGPM 213 fusion protein [15] were used in immuno-localization studies of Pennisetum glaucum resistant protein (PgRP).

\section{MATERIALS AND METHODS}

\subsection{Host and Pathogen}

Pearl millet cultivars IP18296 (highly resistant) with $0 \%$ downy mildew disease incidence (DMDI) and 7042S (highly susceptible) with >25\% DMDI were used. Oomycetous Sclerospora graminicola isolated from pearl millet cv $7042 \mathrm{~S}$ and maintained on the same cultivar under green house conditions was used for all inoculation experiments.

\subsection{Inducer treatment}

\subsubsection{Chitosan treatment}

Seeds of pearl millet cv 7042S were treated with $0.3 \%$ Chitosan with stirring at $26^{\circ} \mathrm{C}\left( \pm 2^{\circ} \mathrm{C}\right)$ for $9 \mathrm{~h}$ with chitosan [17]. Distilled water treated $7042 \mathrm{~S}$ seeds served as control.

\subsection{2 $\beta$-amino butyric acid (BABA) treatment.}

Seeds of cv $7042 S$ were treated with $50 \mathrm{mM}$ DL- $\beta$ aminobutyric acid (BABA, Sigma Chemical Co, St Louis, USA) with stirring at $26 \pm 2{ }^{\circ} \mathrm{C}$ for $6 \mathrm{~h}$ [18]. Distilled water treated $7042 \mathrm{~S}$ seeds served as control.

\subsection{Preparation of samples}

The seeds of chitosan-treated samples were surface sterilized in $0.1 \%$ sodium hypochlorite solution for $15 \mathrm{~min}$, washed thoroughly with sterile distilled water and germinated on moist filter paper under aseptic conditions at $25 \pm 2{ }^{\circ} \mathrm{C}$ in the dark for two days. The two-day-old seedlings were root dip inoculated with $4 \times 10^{4}$ zoospores $\mathrm{ml}^{-1}$ suspension of $S$. graminicola [19]. The inoculated seedlings were harvested at $0,3,6,9,12$ hour post inoculated (h.p.i). Uninoculated seedlings dipped in sterile distilled water served as control. The seedlings were immediately wrapped in aluminium foil and stored at $-70{ }^{\circ} \mathrm{C}$.

\subsection{RNA isolation}

To avoid RNase contamination during RNA extraction glass wares were treated with $0.1 \%$ diethylpyrocarbonate (DEPC) water, sterilized and baked at $160^{\circ} \mathrm{C}$ overnight. All the reagents were prepared with DEPC treated water. Total RNA was extracted according to the standard protocol of Chomzynski et al. [20] and stored at $-70^{\circ} \mathrm{C}$.

The extracted RNA was quantified using spectrophotometer and purity was checked by electrophoresing on $1.2 \%$ formaldehyde agarose (FA) in 1X MOPS (Morpholino Propane Sulphonic acid containing $2 \mathrm{mM}$ MOPS, $0.5 \mathrm{mM}$ sodium acetate and $0.1 \mathrm{mM}$ EDTA) buffer $\mathrm{pH} 7$.

\subsection{Northern blotting}

RNA $(20 \mu \mathrm{g})$ was denatured, separated by electrophoresis, transferred to Hybond-N1 membrane (Amersham Pharmacia, Piscataway, USA) in $20 \times \mathrm{SSC}(3 \mathrm{M}$ sodium chloride, $0.3 \mathrm{M}$ sodium citrate) and fixed to the membrane by baking for 90 min at $80{ }^{\circ} \mathrm{C}$. RNA gel blots were prehybridized in a solution containing $0.25 \mathrm{M}$ sodium phosphate $(\mathrm{pH} 7.2), 0.25 \mathrm{M}$ sodium chloride, $7 \%$ sodium dodecyl sulphate (SDS, w/v) and $1 \mathrm{mM}$ EDTA at $65^{\circ} \mathrm{C}$ for $3 \mathrm{~h}$.

The blots were hybridized with $5 \mu \mathrm{Ci}$ of $\alpha{ }^{32} \mathrm{P}$-labeled clone RGPM213 (AF513969) probe in the same solution overnight at $42^{\circ} \mathrm{C}$. The membranes were washed at $42^{\circ} \mathrm{C}$ twice for $20 \mathrm{~min}$ each in $0.2 \%$ SSC and $0.1 \%$ SDS (w/v). The hybridized blots were exposed to Phospho imager plates for $2-3 \mathrm{~h}$ and scanned with Multifunctional Image Analysis System (FLA 5000, FujiFilm, Tokyo, Japan). Equal loading of total RNA is represented by ethidium bromide stained gel.

\subsection{Confocal-immunofluorescence microscopy-Pennisetum glaucum resistant protein (PgRP) localization.}

The tissue preparation for confocal-immunofluorescence microscopic studies was carried out according to the protocol of the Prestamo et al. [21] with minor modifications. The two-day- 
old pearl millet seedlings of BABA, chitosan inducer treated resistant and susceptible samples were harvested at 6 h.p.i along with their respective control sample.

The harvested samples were fixed in $4 \%(\mathrm{w} / \mathrm{v})$ formaldehyde in $50 \mathrm{mM}$ phosphate buffered saline (PBS) for $2 \mathrm{~h}$ at room temperature. Samples were then washed three times $10 \mathrm{~min}$ each in PBS. Sections (30 $\mathrm{mm}$ thick) were obtained via vibratome (Bio-Rad) and placed onto glutaraldehyde activated and 3-amino propyl trietoxy silane coated slides. Sections were permeabilised with $2 \%(\mathrm{w} / \mathrm{v})$ cellulase in TBS $(25 \mathrm{mM}$ Tris- $\mathrm{HCl}$, $\mathrm{pH} 7.4,140 \mathrm{mM} \mathrm{NaCl}, 3 \mathrm{mM} \mathrm{KCl}$ ) for $30 \mathrm{~min}$ at room temperature. After washing the sections in TBS thrice, 5 min each, the sections were blocked in TBS containing $5 \%$ BSA for $30 \mathrm{~min}$ and then incubated separately with the primary antibodies (antiPgRP; diluted 1:5000 in TBS) for $1 \mathrm{~h}$ at room temperature. Post three washes in TBS, 15 min each, the sections were treated with the secondary antibody (goat anti-rabbit IgG-Atto488 antibody whole molecule produced in goat: diluted 1:2000 in TBS) for $1 \mathrm{~h}$ at room temperature. Finally the sections were washed in TBS as mentioned earlier.

After the final washing step, tissue sections were observed for fluorescence using suitable filter sets for excitation $(485 \mathrm{~nm})$ and emission (506-538 nm) under a LSM-710 laser scanning confocal microscope (Carl Zeiss, Germany). An objective magnification of $20 \mathrm{X}$ with a numeric aperture of $1.3 \mathrm{U}$ was employed. Fluorescent images were acquired through a mounted CCD camera and processed using ZEN 2011 software.

\section{RESULTS}

\subsection{Northern analysis}

In $0.3 \%$ chitosan-treated pearl millet seedlings, the expression pattern of the RGPM 213 was observed as a strong signal at 3 h.p.i followed by a subsequent increase at 6 h.p.i (Fig. 1). This strong signal appeared to likely reduce at the other time intervals of 9 and 12 h.p.i. However in the chitosan-treated control seedlings, a uniform level of transcript of RGPM 213 was recorded. This level was marginally stronger than that observed in the susceptible control.

The expression of the RGPM 213 gene in different regions like coleoptiles and roots of pearl millet seedlings was studied. The expression of RGPM 213 transcript was three times higher in coleoptile region after inoculation with pathogen $S$. graminicola (Fig. 2).

\subsection{Confocal-immunofluorescence microscopy}

To gain information of the intracellular localisation of RGPM 213 resistant protein, immunofluorescence technique was carried out using confocal laser scanning microscope on coleoptiles of 2-day-old pearl millet seedlings harvested at 6 h.p.i. Cross-sections of inoculated seedlings of cv. IP18296 treated with RGPM 213 specific antibody showed strong accumulation of pearl millet resistant protein (PgRP) compared to the control (Fig. 3). The pathogen-induced immunofluoresence was observed in outer epidermal cells, cortical regions with the signals being more intense in the vasculature.

Copious level of immunofluorescence signals were recorded only in the seedlings of cv. IP18296 and inducer (BABA and chitosan) treated seedlings upon $S$. graminicola infection. Seedlings of cv.7042S on the other hand showed poor localisation intensities for PgRP across the tissue cross section with no significant increase post pathogen-treatment (Fig. 3 SC and SI). Negligible signals were observed BABA and Chitosan-treated control coleoptiles cross sections for PgRP specific antibodies (Fig $\mathrm{BC}$ and $\mathrm{CC}$ ). Comparatively significant fluorescence was observed in the inducer inoculated samples (Fig. BI and CI). Treatment of the sections with only secondary-antibody showed no signals (data not shown).

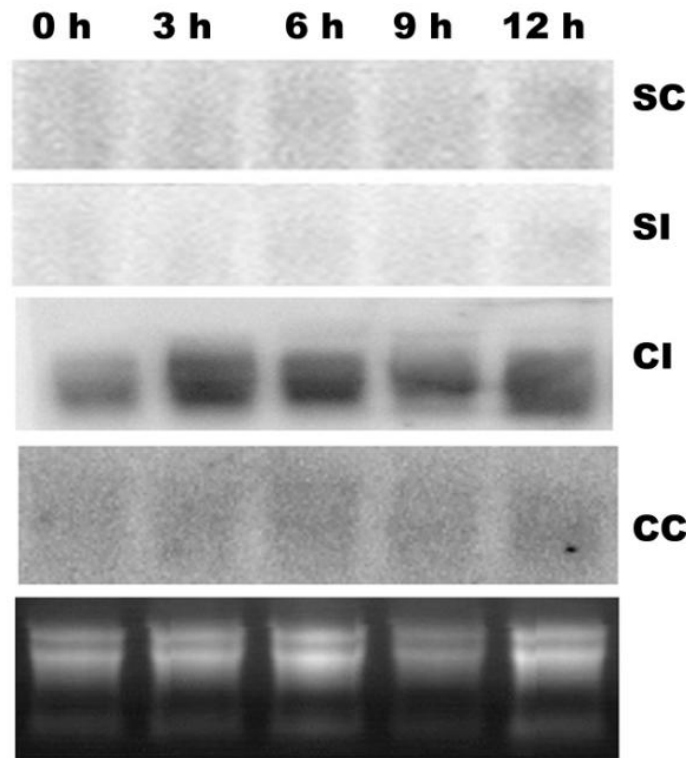

Fig. 1: Accumulation pattern of RGPM213 transcripts in pearl millet after inducer chitosan treatment: SI-susceptible inoculated; SC-susceptible control ; CI - inducer treated 7042 S seeds with chitosan and inoculated with $S$. graminicola ; CC - inducer treated $7042 \mathrm{~S}$ seeds with chitosan and mock inoculated with distilled water. The last gel shows total RNA loading which is represented by ethidium bromide stained gel.

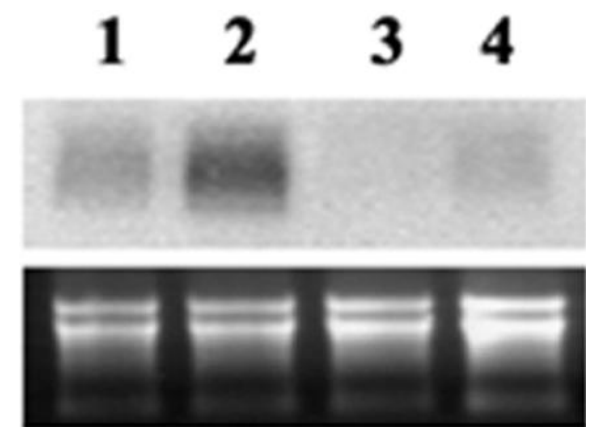

Fig. 2: Accumulation of RGPM213 transcripts in different region of pearl millet seedlings. Northern hybridization of RNA with RGPM213 clone of pearl millet. 1-Coleoptile control; 2-coleoptile inoculated; 3-root control and 4-root inoculated. 


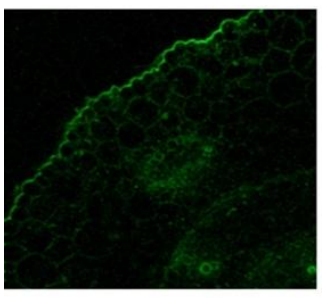

RC

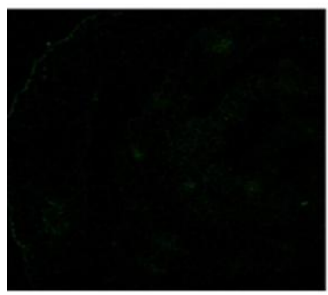

SC

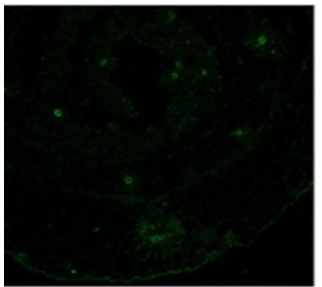

BC

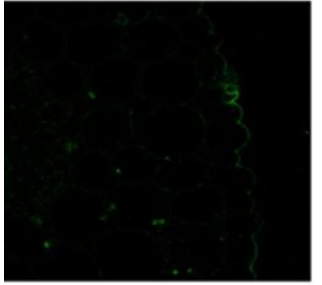

CC

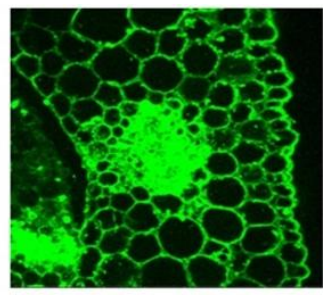

$\mathbf{R I}$

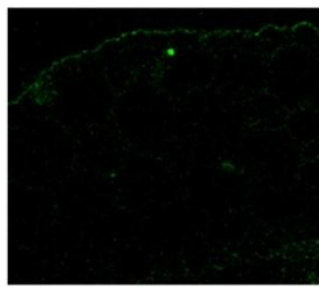

SI

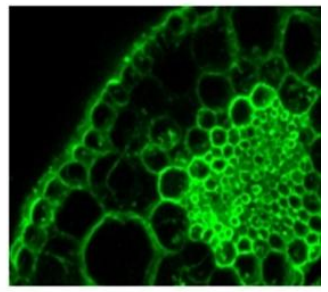

BI

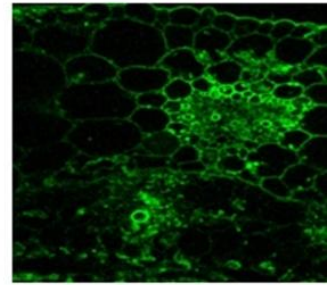

CI
Fig. 3: Immunolocalization of PgRP in cv. 7042S and cv. IP18296 pearl millet seedlings. Cross sections of coleoptile region from two-day-old resistant control (RC), resistant inoculated (RI), susceptible control (SC), susceptible inoculated(SI), BABA control (BC), BABA inoculated (BI), chitosan control (CC), chitosan inoculated (CI) respectively were immunostained using antiPgRP polyclonal antibodies followed by goat anti-rabbit IgG-Atto488 antibody treatment. Tissue sections were observed for green fluorescence using suitable filter sets for excitation $(485 \mathrm{~nm})$ and emission $(506-538 \mathrm{~nm})$ under a LSM710 laser scanning confocal microscope.

\section{DISCUSSION}

Abiotic elicitor-mediated activation of plant resistance response to pathogen stress is popularly being used as an environment-friendly option in sustainable agriculture. It has earlier been exploited in pearl millet defence against the downy mildew pathogen. Abiotic elicitors such as acetyl salicylic acid [22], BABA [23], $\mathrm{H}_{2} \mathrm{O}_{2}, \mathrm{CaCl}_{2}$ [24] and chitosan have been reported to offer good protection against the pathogen under both greenhouse and field conditions by inducing various defencerelated proteins [17]. Immunolocalization study in pearl millet mitogen-activated protein kinase 1 (PgMPK1) during an incompatible interaction has shown high expression of protein in the epidermal and vascular bundle tissue. Further $\mathrm{H}_{2} \mathrm{O}_{2}$, BABA and chitosan inducers showed a strong early induction of PgMPK1 in pearl millet host-pathogen interaction [25]. Microscopic localization study in sunflower has shown that, CC-NBS-LRR class of plant resistance gene transcripionally gets expressed in an incompatible interaction against Plasmopara halstedii [26].

Chitosan, a linear $\beta$ 1,4 glucosamine-polymer derived from chitin is nontoxic, ecofriendly, biodegradable, deacetylated derivative of chitin [27]. Chitosan has shown to have inhibitory effect on growth of many plant pathogens [28, 29]. This compound has shown properties, such as bioactivity and biocompatibility [30]. The research out come from the literature have shown that, when used in plants, chitosan can increase the yield [31], reduce transpiration [32] and induce a range of metabolic changes as a result of which, plants become more resistant to viral, bacterial and fungal infections [33]. In addition, plants treated with chitosan may be less prone to stress stimulated by unfavourable conditions, such as drought, salinity, low or high temperature [34 and 35].

Localization studies on pearl millet defense protein polygalacturonase-inhibitor proteins (PGIPs) has shown very high levels of fluorescence in the epidermal and vascular bundle tissues, with less intense accumulation in the parenchyma beneath in 24 h.p.i samples [36]. In Chorispora bungeana, immunolocalization of defense-related proteins in leaves, stems and roots have shown copious fluorescence in leaves, mainly localized in epidermis, and recorded high in vascular bundles of stems and roots. The fluorescence signal of the control was nearly absent in stem, but not in leaf and root [37]. In Phaseolus vulgaris, during compatible interactions, no significant accumulation of defense-related protein was observed in hypocotyls and a very weak accumulation seen in leaves during lesion formation in Phaseolus vulgaris [38]. During incompatible interaction studies have shown a rapid, intense and transient accumulation of defense-related protein expression in epidermal cells proximal to the site of infection and, less intense, within the cortical parenchyma underneath [39].

Studies on chitosan induced resistance, has shown that it could offer a protection of upto $73 \%$ in pearl millet downy mildew interaction [17]. In pearl millet foliar spray of commercially prepared chitosan preparation has showed $67 \%$ crop protection. In combination of seed treatment and foliar spray to 2day-old seedlings has recorded $71 \%$ protection [40]. The investigation on nature of disease control mechanisms has indicated that it is due to induction of systemic resistance [40]. Although pearl millet roots and coleoptiles regions are easily available for $S$. graminicola infection, majority of the pathogenic microbes are inhabitants of mesocotyl and shoot regions in seedling stage [41]. In northern analysis, detectable RGPM 213 transcript signals were not observed in root region and hence coleoptile region was selected for immnolocalization studies.

\section{CONCLUSION}

In the present study, abiotic inducers like chitosan, BABA and biotic stress of $S$. graminicola on pearl millet RGA was investigated. A significantly higher level of accumulation of 
RGPM 213 transcripts in BABA induced samples [16] and chitosan induced samples is reported. PgRP transcript expression is induced following treatment with the above abiotic inducers of defense. Confocal-immunofluorescence microscopic analysis indicated an accumulation of pearl millet resistant protein (PgRP) in epidermal cells proximal to the site of infection. Thus, with present experimental outcome with PgRP prominently expressed in BABA-treated pearl millet among the tested inducers, it could be stated that BABA-induced resistance could be a PgRP mediated phenomenon.

\section{ACKNOWLEDGMENTS}

We acknowledge the recognition of University of Mysore as an Institution of Excellence by the Government of India with financial support from the Ministry of Human Resource Development and University Grants Commission, India. First author is grateful to Plant Molecular Biology Laboratory, Department of Studies in Biotechnology, University of Mysore, Mysore for providing facilities to carry out experiments.

Financial support and sponsorship: This work was financially supported by the University Grant Commission, New Delhi, India.

Conflict of Interests: There are no conflicts of interest.

\section{REFERENCES}

1. Marone D, Russo MA, Laidò G, De Leonardis AM, Mastrangelo AM. Plant Nucleotide Binding Site-Leucine-Rich Repeat (NBSLRR) Genes: Active Guardians in Host Defense Responses. Int. J. Mol. Sci. 2013; 14: 7302-7326.

2. Kruijit M, De kock M, Dewit P. Receptor like proteins involved in plant disease resistance. Mol Plant Pathol. 2005; 6: 85-97.

3. Leister D, Ballovora A, Salamini F, Gebhardt C. A PCR-based approach for isolating pathogen resistance genes from potato with potential for wide application in plants. Nat Genet. 1996; 14:421-429.

4. Kanazin V, Mareck L, Shoemaker R. Resistance gene analogs are conserved and clustered in soybean. Proc Natl Acad Sci USA. 1996; 93:11746-11750.

5. Song WY, Pi LY, Wang GL, Gardner J, Holsten T. Evolution of the rice Xa21 disease resistance gene family. Plant Cell. 1997; .9:12791287.

6. Aarts N, Metz M, Holub E, Staskawicz BJ, Daniels MJ, Parker JE. Different requirements for EDS1 and NDR1 by disease resistance genes define at least two $R$ gene-mediated signaling pathways in Arabidopsis. Proc Natl Acad Sci USA 1998; 95:10306-10311.

7. Shen K, Meyers B, Islam-Faridi M, Chin D, Stelly D, Michelmore R. Resistance gene candidates identified by PCR with degenerate oligonucleotide primers Map to clusters of resistance genes in lettuce. Mol Plant Microbe In. 1998; 11:815-823.

8. Rivkin M, Vallejos C, McClean P. Disease-resistance related sequences in common bean. Genome. 1999; 42:41-47.

9. Ferrier-Cana E, Geffroy V, Macadre C, Creusot F, Imbert-Bollore P, Sevignac M, Langin T. Characterization of expressed NBS-LRR resistance gene candidates from common bean. Theor Appl Genet. 2003; 106:251-261.

10. He LM, Du CG, Covaleda L, Xu ZY, Robinson AF, Yu JZ, Kohel RJ, Zhang HB. Cloning, characterization, and evolution of the NBSLRR encoding resistance gene analogue family in polyploidy cotton (Gossypium hirsutum L). Mol Plant Microbe In. 2003; 17:1234-1241.
11. Zhu Q, Bennetzen JL., Smith SM. Isolation and diversity analysis of resistance gene homologues from switchgrass. Gen Soc America. 2013; 3:1031-42.

12. Backiyarani S., Uma S., Arunkumar G., Saraswathi MS and. Sundararaju P. Cloning and characterization of NBS-LRR resistance gene analogues of Musa spp. and their expression profiling studies against Pratylenchus coffeae. Afr Jour Biotech. 2013; 12:4256-4268.

13. Wan, H.; Yuan, W.; Bo, K.; Shen, J.; Pang, X.; Chen, J. Genomewide analysis of NBS-encoding disease resistance in Cucumis sativus and phylogenetic study of NBS-encoding genes in Cucurbitaceae crops. BMC Genomics. 2013; 14: 109.

14. Ramadevi, Vijayakumar S, Venkateswara R K, Dashavantha R V. Transgenic Pearl millet male fertility restorer line (ICMP451) and hybrid (ICMH451) expressing brassica juncea nonexpressor of pathogenesis related genes 1 (BjNPR1) exhibit resistance to downy mildew disease. Plant Sci. 2014; 9(3):1-10.

15. Ranjini P, Shailasree S, Kini RK and Shetty HS. Isolation and characterization of NBS-LRR resistance gene analog from pearl millet. APPP. 2011; 44:1013-1023.

16. Ranjini P, Shailasree S, Kini RK and Shetty HS. Transcripts of resistance gene candidates accumulate in pearl millet as a response to infection by Sclerospora graminicola. JMPP. 2006; 36:411-414.

17. Manjunath G, Roopa KS, Geetha NP, Shetty HS. Chitosan enhances disease resistance in pearl millet against downy mildew caused by Sclerospora graminicola and defense- related enzyme activation. Pest Manag Sci. 2008; 1250-1257.

18. Shailasree S, Sarosh BR, Vasanthi NS, Shetty HS. Seed treatment with $\beta$-amino butyric acid protects Pennisetum glaucum systemically from Sclerospora graminicola. Pest Manag Sci. 2001; 57:721-728.

19. Safeeulla KM. Biology and Control of the Downy Mildews of Pearl Millet, Sorghum and Finger Millet. (Wesley Press: Mysore). 1976. pp 304.

20. Chomzynski P, Sacchi N. Single step method of RNA isolation by acid guanidinium thiocynate-phenol-chloroform extraction. Anal Biochem. 1987; 162:156-159.

21. Prestamo PT, Vicente O, Gonzalez-Melendi P, Coronado M, Wilson C, Heberle-Bors E, Risueno M. Ultrastructural distribution of a MAP kinase and transcripts in quiescent and cycling plant cells and pollen grains. J Cell Sci. 1999; 112:1065-1076.

22. Shivakumar P, Vasanthi N, Shetty H, Petersen VS. Ribonucleases in the seedlings of pearl millet and their involvement in resistance againstdowny mildew disease. Eur J Plant Pathol. 2000; 106:825-836.

23. Shailasree S, Kini R, Shetty H. Beta-amino butyric acid induced resistance in pearl millet to downy mildew is associated with accumulation of defense-related proteins. Australas Plant Pathol. 2007; 36:204-211.

24. Geetha $\mathrm{H}$, Shetty $\mathrm{H}$. Induction of resistance in pearl millet against downymildew disease caused by Sclerospora graminicola using benzothiadiazole, calcium chloride and hydrogen peroxide - a comparative evaluation, Crop Prot. 2002; 21: 601-610.

25. Melvin P, Prabhu SA, Anup CP, Shailasree S, Shetty HS, Kini KR Involvement of mitogen-activated protein kinase signaling in pearl millet-downy mildew interaction. Plant Sci. 2014; 214:29-37.

26. Radwan $\mathrm{O}$, Mouzeyar S, Nicolas, Bouzidi F. Induction of a sunflower CC-NBS-LRR resistance gene analogue during incompatible interaction with Plasmopara halstedii. J Expt Bot. 2005; 56: 567-575.

27. Hadrami E, A, Adam LR, Hadrami IE, Daayf F. Chitosan in plant protection. Marine Drugs. 2010; 8: 968-987.

28. Roller $\mathrm{S}$ and Covill $\mathrm{N}$. The antifungal properties of chitosan in laboratory media and apple juice. Int Food Microb. 1999; 47:67-77.

29. Rhoades J and Roller S. Antimicrobial action of degraded and native chitosan against spoilage organisms in laboratory media and foods. Appl Environ Microb. 2000; 66:80-86.

30. Dias AMA, Cortez AR, Barsan MM, Santos JB, Brett CMA, De Sousa HC. Development of greener multi-responsive chitosan 
biomaterials doped with biocompatible ammonium ionic liquids. ACS Sustainable Chem Eng. 2013; 1: 1480-1492.

31. Mondal MMA, Malek MA, Puteh AB, Ismail MR, Ashrafuzzaman M, Naher L. Effect of foliar application of chitosan on growth and yield in okra. Aust J Crop 2012; 6: 918-921.

32. Dzung NA, Khanh VTP, Dzung TT. Research on impact of chitosan oligomers on biophysical characteristics, growth, development and drought resistance of coffee. Carbohydr Polym. 2011; 84: 751-755.

33. Al-Hetar MY, Zainal Abidin MA, Sariah M, Wong MY. Antifungal activity of chitosan against Fusarium oxysporum f. sp. Cubense. J Appl Polym Sci, 2011; 120: 2434-2439.

34. Lizarraga-Pauli EG, Torres-Pacheco I, Moreno-Martinez E, MirandaCastro SP. Chitosan application in maize (Zea mays) to counteract the effects of abiotic stress at seedling level. Afr J Biotechnol. 2011; 10: 6439-6446.

35. Jabeen N, Ahmad R. The activity of antioxidant enzymes in response to salt stress in safflower (Carthamus tinctorius L.) and sunflower (Helianthus annuus L.) seedlings raised from seed treated with chitosan. J Sci Food Agr 2013; 93: 1699-1705.

36. Prabhu S, Wagenknecht M, Melvin P, Gnanesh Kumar BS, Veena M, Shailasree S, Moerschbacher BM, Ramachandra Kini K. Immuno-affinity purification of PglPGIP1, a polygalacturonaseinhibitor protein from pearl millet: studies on its inhibition of fungal polygalacturonases and role in resistance against the downy mildew pathogen. Mol Biol Rep. 2015; 42:1123-1138.

37. Di C-X, Li M, Long F. Molecular cloning, functional analysis and localization of a novel gene encoding polygalacturonase-inhibiting protein in Chorispora bungeana. Planta. 2009; 231:169-178.

38. Devoto A, Clark A, Nuss L. Developmental and pathogen-induced accumulation of transcripts of polygalacturonase-inhibiting protein in Phaseolus vulgaris L. Planta 1997; 202:284-292.
39. Bergmann C, Ito Y, Singer D. Polygalacturonaseinhibiting protein accumulates in Phaseolus vulgaris L. in response to wounding, elicitors and fungal infection. Plant J 1994; 5:625-634.

40. Sharathchandra RG, Niranjan Raj S, Shetty NP, Amruthesh KN and Shetty HS. A Chitosan formulation Elexa ${ }^{\mathrm{TM}}$ induces downy mildew disease resistance and growth promotion in pearl millet. Crop prot. 2004; 23(10) 881-888.

41. Sharada M, Shetty S, Shetty H. Infection process of Sclerospora graminicola on Pennisetum glaucum lines resistant and susceptible to downy mildew. Mycol Res. 1995;99:317-322.

\section{How to cite this article:}

Ranjini P, Prasad M, Kumar JS, Sekhar S, Kesagodu D, Shetty HS, Kini KR. Chitosan and $\beta$-amino butyric acid up-regulates transcripts of resistance gene analog RGPM213 in pearl millet to infection by downy mildew pathogen. J App Biol Biotech. 2016; 4 (05): 001-006. doi: 10.7324/JABB.2016.40501 